\title{
Physico-Chemical, Microbiological and Sensory Qualities of Puree Produced From Two Cultivars of Tomato (Lycopersicon esculentum) Under Ambient Storage
}

\author{
Olajide E. Adedeji ${ }^{1}$, Julian C. Anuonye ${ }^{2}$, Fortune A. Ekundayo ${ }^{3}$, Taye F. Olaoye ${ }^{4}$, Abibat O. Babalola ${ }^{5} \&$ \\ Gbenga J. Ogundahunsi ${ }^{6}$ \\ ${ }^{1}$ Department of Food Science and Technology, Federal University Wukari, Nigeria \\ ${ }^{2}$ Department of Food Science and Technology, Federal University of Technology, Minna, Nigeria \\ ${ }^{3}$ Department of Human Nutrition, University of Ibadan, Nigeria \\ ${ }^{4}$ Department of Food Technology, Gent University, Belgium \\ ${ }^{5}$ Department of Nutrition and Dietetics, Federal Polytechnic, Ede, Nigeria \\ ${ }^{6}$ Department of Biochemistry, Adekunle Ajasin University Akungba Akoko, Nigeria \\ Correspondence: Olajide E. Adedeji, Department of Food Science and Technology, Federal University Wukari, \\ PMB 1020 Wukari, Taraba State, Nigeria. Tel: 234-803-060-8536. E-mail: adedeji@fuwukari.edu.ng
}

\author{
Received: November 12, 2014 Accepted: January 4, 2015 Online Published: January 28, 2015 \\ doi:10.5539/jfr.v4n2p143 URL: http://dx.doi.org/10.5539/jfr.v4n2p143
}

\begin{abstract}
Tomato purees were produced from De Rica and Roma cultivars of tomato, packaged in high density polyethylene and stored at ambient temperature $\left(32 \pm 2{ }^{\circ} \mathrm{C}\right)$. The stored purees were analysed weekly for physicochemical composition, sensory attributes and microbial load until they became unwholesome. There was a significant $(\mathrm{p}<0.05)$ falling in Titratable Acidity (TTA) within the first five and six weeks for De Rica and Roma purees respectively. TTA values dropped from 12.43 to 8.40 and 10.69-7.43 for De Rica and Roma purees respectively. Total solid (TS) of the purees decreased significantly $(\mathrm{p}<0.05)$ from $16.2 \%$ to $9.08 \%$ for De Rica puree and $17.89 \%$ to $9.99 \%$ for Roma puree within the first four weeks of storage and became stable at the later weeks of storage. Roma puree had higher TS throughout the storage period. Total Insoluble Solid of the purees increased significantly from $3.07 \%$ and $4.01 \%$ for De Rica puree and $2.3 \%$ and $3.44 \%$ for Roma puree within the first week of storage. The values however, decreased significantly is $(\mathrm{p}<0.05)$ at the second week of storage from $4.01 \%$ to $1.19 \%$ for De Rica puree and $3.44 \%$ to $1.89 \%$ for Roma puree. The bulk density of the samples decreased significantly $(\mathrm{p}<0.05$ ) from $1.14 \mathrm{~g} / \mathrm{ml}$ to $0.95 \mathrm{~g} / \mathrm{ml}$ for De Rica puree and $1.12 \mathrm{~g} / \mathrm{ml}$ to $0.95 \mathrm{~g} / \mathrm{ml}$ for Roma puree through the storage period. There was an insignificant $(\mathrm{p}>0.05)$ increase in total bacteria count from $140 \mathrm{CFU} / \mathrm{g}$ to $320 \mathrm{CFU} / \mathrm{g}$ for De Rica puree and $126 \mathrm{CFU} / \mathrm{g}$ to $280 \mathrm{CFU} / \mathrm{g}$ for Roma puree within the first two weeks of storage. The values increased significantly $(\mathrm{p}<0.05)$ from $640 \mathrm{CFU} / \mathrm{g}$ to $137,000 \mathrm{CFU} / \mathrm{g}$ for De Rica puree and $590 \mathrm{CFU} / \mathrm{g}$ to 122,000 for Roma puree from the third to the tenth week of storage. There was no significant difference ( $>0.05$ ) between the freshly produced De Rica puree, Roma puree and the commercial sample in appearance, colour, taste and overall acceptability before and during storage. Marked rejection of the purees was observed at the eight week of storage.
\end{abstract}

Keywords: tomato puree, De Rica, Roma, storage

\section{Introduction}

Tomato is one of the most commonly cultivated and consumed vegetable fruit (Temesgen et al., 2011). Most cultivars produce red fruit but a number of cultivars with yellow, orange, pink, purple, green black and white fruits are also available (Peet, 2008).

Tomato is commonly used in sauces, salad and in soups (Omole, 2002). It is rich in vitamins B, C and minerals like iron, sodium, potassium as well as trace amounts of protein and carbohydrate (Malcolm, 1997). Tomato is also a rich source of lycopene, a natural pigment which gives tomato its red colour. Lycopene, an antioxidant noted for its ability to protect DNA and prevent diseases continues to be the subject of studies on heart diseases and cancer (Levy, 2009). 
Tomato puree is a processed food product consisting only of pulped tomatoes as its major ingredient. It is usually prepared by vacuum concentration of tomato juice and must contain at least $8.37 \%$ of tomato solids (Ihekoronye \& Ngoddy, 1985). Tomato puree has been found to be nutritionally better than other forms of processed tomato such as tomato ketchups, tomato paste and tomato sauce (Levy, 2009). Unlike most fruits and vegetables where nutritional content decreases with cooking, processing tomato into puree increases the concentration of bioavailable lycopene (Levy, 2009). According to Gould (1983), the rationale for concentration of tomato puree is to reduce the moisture content and increase the acidity to a level that will prolong shelf life during storage, to reduce colonization by microorganisms and to make tomato available all year round.

The quality of tomato products differ with respect to tomato cultivar (Temesgen et al., 2011). Opara et al. (2012) reported changes in physicochemical properties and nutritional contents of three green house grown tomato cultivars. This present study was conducted to compare the physicochemical, microbial and sensory properties of two cultivars (De Rica and Roma) of tomato commonly cultivated in Nigeria.

\section{Materials and Methods}

\subsection{Materials}

The materials (De Rica and Roma cultivars of tomato) were obtained from New Market, Minna, in Niger state. The research was carried out in Water Quality Laboratories, Upper River Niger Basin, Tundun Fulani, Minna, Food Science and Technology and Chemistry Departments' Laboratories of Federal University of Technology, Minna.

\subsection{Methods}

\subsubsection{Preparation of Tomato Puree}

De Rica and Roma purees were produced using the hot break method as described by Idowu (2001). Subsequently, the processed tomato puree was filled into squeezable tubes (made of high density polyethylene) with the aid of a hand pump (Ateco icing set, model E20, made in Japan) in a sterile environment.

\subsubsection{Storage}

The packaged tomato purees were stored in a clean environment at ambient temperature $\left(32 \pm 2{ }^{\circ} \mathrm{C}\right)$. The packaged products were analysed weekly for physicochemical composition (moisture, $\mathrm{pH}$, total solid, titratable acidity, total soluble solid, total insoluble solid, chloride, sucrose and bulk density), acceptability analysis and microbial stability until the products became unwholesome.

\subsubsection{Sample Analyses}

$\mathrm{pH}$, titratable acidity, moisture content were determined using standard methods (AOAC, 2000), total solid, total soluble and insoluble solids, and bulk density were determined using the Standard Methods Committee (2007), chloride and sucrose contents were determined using Nielsen methods (1998).

Total plate, yeast/mold and total coliform counts were carried out using the procedures outlined by Robert and Greenwood (2003).

A sensory evaluation of freshly prepared tomato puree was carried out using a nine-point hedonic scale as described by Ihekoronye and Ngoddy, (1985). 32 panelists comprising civil servants and students, males and females alike were used. The panelists were presented five coded samples of De Rica, Roma purees and a control commercial sample. They were asked to compare the quality of the samples for colour, taste, appearance and overall acceptability

The data obtained were subjected to statistical analysis. The mean values were separated using Duncan Multiple Range Test and the significant differences between samples were tested using one-way analysis of variance (ANOVA) using SPSS (Statistical Package for the Social Scientists) version 16.0, Windows 2006.

\section{Results and Discussions}

\subsection{Physicochemical Changes of Tomato Puree With Time}

The changes in Total Solid (TS), Total Soluble Solid (TSS) Total Insoluble Solid (TIS), pH, Titratable Acidity (TTA), Moisture Content, Bulk Density, Chloride and Sucrose Contents of De Rica and Roma purees overtime are shown in Table 1. TS of the purees decreased significantly $(\mathrm{p}<0.05)$ from $16.2 \%$ to $9.08 \%$ for De Rica puree and from $17.89 \%$ to $9.99 \%$ for Roma puree within the first four weeks of storage and became stable at the later weeks of storage. Roma puree had higher TS throughout the storage period. TSS of the purees showed a significant decrease $(\mathrm{p}<0.05)$ in values with Roma puree having a higher value throughout the period of storage. De Rica puree decreased from $13.13 \%$ to $6.86 \%$ while Roma puree decreased from $15.59 \%$ to $4.81 \%$ within the 
first five weeks of storage and became stable at the later period of the storage. There was a decrease in values of TS and TSS during storage probably due to the breakdown of pectin and the inhibition of low methoxyl pectin which might have occurred as reported for concentrated low acid vegetable foods (Adedeji et al., 2012).TIS of the purees increased significantly $(\mathrm{p}<0.05$ ) from $3.07 \%$ to $4.01 \%$ for De Rica puree and from $2.3 \%$ to $3.42 \%$ for Roma puree within the first week of storage. The values however, decreased significantly $(\mathrm{p}<0.05)$ during the second week of storage from $4.01 \%$ to $1.19 \%$ for De Rica puree and from $3.42 \%$ to $2.66 \%$ for Roma puree. The value increased significantly for both purees at the third week of storage and became stable at the later weeks of storage. Total insoluble solid showed a significant increase $(\mathrm{p}<0.05)$ at the initial period of storage probably due to serum sedimentation in the purees which is a major problem of puree produced by the hot break method (Moyer, 2000).

Table 1. Mean weekly physicochemical scores of De Rica and Roma purees

\begin{tabular}{|c|c|c|c|c|c|c|c|c|c|c|}
\hline \multirow{2}{*}{ Parameter } & \multirow{2}{*}{ Sample } & \multicolumn{9}{|c|}{ Weeks } \\
\hline & & 0 & 1 & 2 & 3 & 4 & 5 & 6 & 7 & 8 \\
\hline \multirow[t]{2}{*}{ TTA } & De Rica & $12.43 \pm 0.28^{\mathrm{a}}$ & $11.22 \pm 0.28^{\mathrm{b}}$ & $9.08 \pm 0.28^{\mathrm{c}}$ & $8.62 \pm 0.28^{\mathrm{d}}$ & $8.50 \pm 0.28^{\mathrm{d}}$ & $8.40 \pm 0.28^{\mathrm{e}}$ & $8.43 \pm 0.28^{\mathrm{e}}$ & $8.43 \pm 0.28^{\mathrm{e}}$ & $8.43 \pm 0.00^{\mathrm{e}}$ \\
\hline & Roma & $10.69 \pm 0.28^{\mathrm{a}}$ & $9.24 \pm 0.28^{b}$ & $8.62 \pm 0.28^{\mathrm{c}}$ & $7.72 \pm 0.28^{\mathrm{d}}$ & $7.49 \pm 0.00^{\mathrm{e}}$ & $7.47 \pm 0.00^{\mathrm{e}}$ & $7.43 \pm 0.28^{\mathrm{e}}$ & $7.41 \pm 0.28^{\mathrm{e}}$ & $7.41 \pm 0.28^{\mathrm{e}}$ \\
\hline \multirow[t]{2}{*}{ TS } & De Rica & $16.20 \pm 0.00^{\mathrm{a}}$ & $15.39 \pm 0.28^{b}$ & $11.17 \pm 0.28^{\mathrm{c}}$ & $9.06 \pm 0.84^{\mathrm{f}}$ & $9.08 \pm 0.28^{\mathrm{f}}$ & $9.79 \pm 0.28^{\mathrm{e}}$ & $9.97 \pm 0.00^{\mathrm{e}}$ & $10.28 \pm 0.28^{\mathrm{d}}$ & $10.28 \pm 0.28^{d}$ \\
\hline & Roma & $17.89 \pm 0.28^{\mathrm{a}}$ & $15.89 \pm 0.00^{\mathrm{b}}$ & $12.96 \pm 0.28^{\mathrm{c}}$ & $10.5 \pm 0.28^{\mathrm{d}}$ & $9.99 \pm 0.28^{\mathrm{e}}$ & $8.78 \pm 0.28^{f}$ & $8.80 \pm 0.28^{\mathrm{f}}$ & $9.94 \pm 0.78^{\mathrm{e}}$ & $9.89 \pm 0.28^{\mathrm{e}}$ \\
\hline \multirow[t]{2}{*}{ TSS } & De Rica & $13.13 \pm 0.28^{\mathrm{a}}$ & $11.18 \pm 0.28^{b}$ & $9.98 \pm 0.28^{\mathrm{c}}$ & $6.24 \pm 0.28^{\mathrm{f}}$ & $6.17 \pm 0.28^{\mathrm{f}}$ & $6.86 \pm 0.28^{\mathrm{e}}$ & $6.91 \pm 0.28^{\mathrm{e}}$ & $7.75 \pm 0.28^{\mathrm{d}}$ & $7.69 \pm 0.28^{d}$ \\
\hline & Roma & $15.59 \pm 0.71^{\mathrm{a}}$ & $12.48 \pm 0.14^{b}$ & $11.07 \pm 0.00^{\mathrm{c}}$ & $6.57 \pm 0.28^{d}$ & $6.05 \pm 0.28^{\mathrm{e}}$ & $4.81 \pm 0.28^{\mathrm{g}}$ & $5.10 \pm 0.28^{\mathrm{f}}$ & $6.16 \pm 0.28^{\mathrm{e}}$ & $6.15 \pm 0.28^{\mathrm{e}}$ \\
\hline \multirow[t]{2}{*}{ TIS } & De Rica & $3.07 \pm 0.28^{b}$ & $4.01 \pm 0.28^{\mathrm{a}}$ & $1.19 \pm 0.28^{\mathrm{e}}$ & $2.88 \pm 0.28^{\mathrm{c}}$ & $2.91 \pm 0.28^{\mathrm{c}}$ & $2.93 \pm 0.28^{\mathrm{c}}$ & $3.06 \pm 0.28^{b}$ & $2.53 \pm 0.28^{\mathrm{d}}$ & $2.54 \pm 0.28^{\mathrm{d}}$ \\
\hline & Roma & $2.30 \pm 0.28^{\mathrm{e}}$ & $3.42 \pm 0.00^{\mathrm{c}}$ & $2.66 \pm 1.12^{\mathrm{d}}$ & $2.91 \pm 1.14^{\mathrm{d}}$ & $3.94 \pm 0.21^{\mathrm{a}}$ & $3.95 \pm 0.01^{\mathrm{a}}$ & $3.83 \pm 0.22^{\mathrm{a}}$ & $3.72 \pm 0.00^{\mathrm{b}}$ & $3.70 \pm 0.00^{\mathrm{b}}$ \\
\hline \multirow[t]{2}{*}{$\mathrm{CL}$} & De Rica & $0.21 \pm 0.28^{\mathrm{d}}$ & $0.33 \pm 0.28^{\mathrm{c}}$ & $0.37 \pm 0.28^{\mathrm{c}}$ & $0.53 \pm 0.28^{\mathrm{a}}$ & $0.41 \pm 0.28^{\mathrm{b}}$ & $0.35 \pm 0.28^{\mathrm{c}}$ & $0.30 \pm 0.28^{\mathrm{d}}$ & $0.24 \pm 0.28^{\mathrm{e}}$ & $0.20 \pm 0.28^{\mathrm{f}}$ \\
\hline & Roma & $0.52 \pm 0.28^{b}$ & $0.54 \pm 0.28^{b}$ & $0.59 \pm 0.28^{\mathrm{a}}$ & $0.61 \pm 0.00^{\mathrm{a}}$ & $0.44 \pm 0.28^{\mathrm{c}}$ & $0.33 \pm 0.00^{d}$ & $0.27 \pm 0.28^{\mathrm{d}}$ & $0.22 \pm 0.28^{\mathrm{e}}$ & $0.22 \pm 0.28^{\mathrm{e}}$ \\
\hline \multirow[t]{2}{*}{ BLD } & De Rica & $1.14 \pm 0.28^{\mathrm{a}}$ & $1.11 \pm 0.28^{b}$ & $1.07 \pm 0.28^{\mathrm{c}}$ & $1.04 \pm 0.28^{\mathrm{d}}$ & $1.02 \pm 0.28^{\mathrm{de}}$ & $1.01 \pm 0.28^{\mathrm{e}}$ & $1.00 \pm 0.00^{\mathrm{e}}$ & $0.98 \pm 0.00^{\mathrm{f}}$ & $0.98 \pm 0.28^{\mathrm{f}}$ \\
\hline & Roma & $1.12 \pm 0.28^{\mathrm{a}}$ & $1.1 \pm 0.28^{\mathrm{a}}$ & $1.10 \pm 0.28^{\mathrm{a}}$ & $1.07 \pm 0.28^{\mathrm{b}}$ & $1.05 \pm 0.28^{\mathrm{b}}$ & $1.03 \pm 0.28^{b}$ & $1.00 \pm 0.28^{\mathrm{c}}$ & $0.98 \pm 0.28^{\mathrm{d}}$ & $0.95 \pm 0.28^{d}$ \\
\hline \multirow[t]{2}{*}{$\mathrm{MC}$} & De Rica & $83.80 \pm 0.00^{d}$ & $84.61 \pm 0.28^{d}$ & $88.83 \pm 0.28^{\mathrm{c}}$ & $90.88 \pm 0.28^{\mathrm{a}}$ & $90.92 \pm 0.28^{\mathrm{a}}$ & $90.21 \pm 0.28^{\mathrm{a}}$ & $90.03 \pm 0.28^{\mathrm{a}}$ & $89.72 \pm 0.28^{b}$ & $89.70 \pm 0.28^{\mathrm{b}}$ \\
\hline & Roma & $82.11 \pm 0.28^{\mathrm{e}}$ & $87.04 \pm 0.28^{d}$ & $89.05 \pm 0.28^{\mathrm{c}}$ & $90.01 \pm 0.28^{b}$ & $91.22 \pm 0.28^{\mathrm{a}}$ & $91.20 \pm 0.28^{\mathrm{a}}$ & $91.19 \pm 0.28^{\mathrm{a}}$ & $90.12 \pm 0.28^{b}$ & $90.07 \pm 0.28^{\mathrm{b}}$ \\
\hline \multirow[t]{2}{*}{ SUC } & De Rica & $11.09 \pm 0.00^{\mathrm{f}}$ & $11.40 \pm 0.28^{\mathrm{e}}$ & $12.20 \pm 0.28^{\mathrm{c}}$ & $12.80 \pm 0.28^{\mathrm{b}}$ & $13.00 \pm 0.28^{\mathrm{a}}$ & $12.15 \pm 0.28^{\mathrm{c}}$ & $12.05 \pm 0.28^{\mathrm{f}}$ & $11.80 \pm 0.28^{\mathrm{d}}$ & $11.78 \pm 0.28^{\mathrm{d}}$ \\
\hline & Roma & $13.00 \pm 0.28^{\mathrm{e}}$ & $13.70 \pm 0.28^{\mathrm{c}}$ & $14.10 \pm 0.28^{b}$ & $14.30 \pm 0.28^{b}$ & $15.00 \pm 0.28^{\mathrm{a}}$ & $14.20 \pm 0.28^{b}$ & $13.20 \pm 0.28^{\mathrm{d}}$ & $12.70 \pm 0.28^{\mathrm{e}}$ & $11.90 \pm 0.28^{\mathrm{f}}$ \\
\hline \multirow[t]{2}{*}{$\mathrm{pH}$} & De Rica & $4.24 \pm 0.28 \mathrm{a}$ & $4.35 \pm 0.28 \mathrm{a}$ & $4.36 \pm 0.28 \mathrm{a}$ & $4.36 \pm 0.28 \mathrm{a}$ & $4.37 \pm 0.28 \mathrm{a}$ & $4.37 \pm 0.00 \mathrm{a}$ & $4.38 \pm 0.00 \mathrm{a}$ & $4.38 \pm 0.00 \mathrm{a}$ & $4.38 \pm 0.00 \mathrm{a}$ \\
\hline & Roma & $4.30 \pm 0.28 \mathrm{a}$ & $4.32 \pm 0.28 \mathrm{a}$ & $4.32 \pm 0.28 \mathrm{a}$ & $4.37 \pm 0.00 \mathrm{a}$ & $4.39 \pm 0.28 \mathrm{a}$ & $4.39 \pm 0.00 \mathrm{a}$ & $4.39 \pm 0.00 \mathrm{a}$ & $4.39 \pm 0.00 \mathrm{a}$ & $4.39 \pm 0.00 \mathrm{a}$ \\
\hline
\end{tabular}

Values are means \pm standard deviation of duplicate scores. Values followed by different superscript in row are significantly different $(\mathrm{p}<0.05)$. Key: TTA Titratable Acidity, TS Total Solid, TSS Total Soluble Solid, TIS, Total Insoluble Solid, CL Chloride, BLD Bulk Density, MC Moisture Content, SUC Sucrose.

The TTA for both purees decreased significantly $(\mathrm{p}<0.05)$ from $12.43 \%$ to $8.5 \%$ for De Rica puree and from $10.69 \%$ to $7.49 \%$ for Roma puree within the first four weeks of storage. The values later became stable at the fifth week onward for both purees. De Rica puree had higher TTA throughout the storage period. TTA showed a significant decrease $(\mathrm{p} \leq 0.05)$ in values that was lower than (9.0) reported by Kirk and Sawyer (1991). This might probably be due to reduction in the pyrilidone carboxylic acid and hydroxylmethyl furfural contents which is formed during concentration of tomato puree (Moyer, 2000). Sucrose contents of the samples increased significantly $(\mathrm{p}<0.05)$ from $11 \%$ to $13 \%$ for Roma puree and from $13 \%$ to $15 \%$ for De Rica puree within the first five weeks of storage before the values became stable for both purees. The $\mathrm{pH}$ of the samples did not show a significant ( $\mathrm{p}>0.05$ ) increase in values throughout the storage period, and it ranged from 4.24 to 4.39 . This $\mathrm{pH}$ of the samples were within the values (4.0-4.4) reported by Kirk and Sawyer (1991). This could probably be due to the inhibition of slime producing microorganisms such as Bacillus by pasteurization. According to Gould (1983), certain strains of Bacillus usually produce substances that increase the alkalinity of tomato puree. The increase in 
content of sucrose observed at the initial phase of storage could probably be due to the formation of amadori compounds especially fructose-glutamic acid that are formed during storage at ambient temperature (Adedeji et al., 2012).

The bulk density of the samples decreased significantly ( $<<0.05$ ) from $1.14 \mathrm{~g} / \mathrm{ml}$ to $0.98 \mathrm{~g} / \mathrm{ml}$ for De Rica puree and from $1.12 \mathrm{~g} / \mathrm{ml}$ to $0.95 \mathrm{~g} / \mathrm{ml}$ for Roma puree through the storage period. Chloride contents of the samples increased significantly $(\mathrm{p}<0.05)$ from $0.21 \%$ to $0.53 \%$ for De Rica puree and from $0.52 \%$ to $0.61 \%$ for Roma puree within first three weeks of storage. The values declined from $0.53 \%$ to $0.2 \%$ for De Rica puree and from $0.61 \%$ to $0.22 \%$ for Roma puree from the third week to the eight week of storage. The bulk density of the samples showed a decrease in value throughout the storage period probably due to the decrease in weight and increase in volume of the samples as a result of reduction in total solid with storage (Francisco et al., 2009).

The moisture content of De Rica puree significantly $(\mathrm{p}<0.05)$ increased from $83.8 \%$ to $90.92 \%$ between the production date and the fourth week of storage and stabilized from the fifth week of storage onward. The moisture content of Roma puree increased significantly ( $p<0.05$ ) from $82.11 \%$ to $91.22 \%$ from production date to the fifth week of storage and later stabilized from the sixth to eight week of storage. The moisture contents of the samples showed increase in value as a result of the decrease in the total solid content of the samples (Adedeji et al., 2012).

The chloride content showed a significant $(\mathrm{p} \leq 0.05)$ increase in value at the initial phase of storage before it reduced significantly $(\mathrm{p} \leq 0.05)$ at the later part of the storage period. This could be due to the fact that chloride becomes more bio available in tomato puree during storage. Gould (1983) had reported increase in nutritional composition of tomato puree during processing and storage unlike most other fruits and vegetables.

\subsection{Microbial Changes of Tomato Puree With Time}

Results of the changes in microbial concentration of the samples with time are shown in Table 2. There was an insignificant increase (p>0.05) from $140 \mathrm{CFU} / \mathrm{g}$ to $320 \mathrm{CFU} / \mathrm{g}$ for De Rica puree and from $126 \mathrm{CFU} / \mathrm{g}$ to 280 CFU/g for Roma puree within the first two weeks of storage. The values increased significantly $(\mathrm{p}<0.05)$ from $640 \mathrm{CFU} / \mathrm{g}$ to $137,000 \mathrm{CFU} / \mathrm{g}$ for De Rica puree and $590 \mathrm{CFU} / \mathrm{g}$ to 122,000 for Roma puree from the third to the tenth week of storage. De Rica puree had higher bacteria count throughout the storage period.

Table 2. Mean weekly microbial scores for De Rica and Roma purees

\begin{tabular}{|c|c|c|c|c|c|c|c|c|}
\hline Weeks & TVC (De Rica) & TVC (Roma) & $\mathrm{MC}($ De Rica) & MC (Roma) & YC (De Rica) & YC (Roma) & Coliform (De Rica) & Coliform (Roma) \\
\hline 0 & $140 \pm 28.82^{\mathrm{i}}$ & $126 \pm 0.00^{\mathrm{k}}$ & $0.00 \pm 0.00^{\mathrm{e}}$ & $0.00 \pm 0.00^{\mathrm{e}}$ & $0.00 \pm 0.00^{\mathrm{f}}$ & $0.00 \pm 0.00^{\mathrm{f}}$ & ND & ND \\
\hline 1 & $230 \pm 28.82^{\mathrm{h}}$ & $210 \pm 7.07^{\mathrm{j}}$ & $0.00 \pm 0.00^{\mathrm{e}}$ & $0.00 \pm 0.00^{\mathrm{e}}$ & $0.00 \pm 0.00^{\mathrm{f}}$ & $0.00 \pm 0.00^{\mathrm{f}}$ & ND & ND \\
\hline 2 & $320 \pm 0.00^{\mathrm{g}}$ & $280 \pm 0.00^{\mathrm{i}}$ & $0.00 \pm 0.00^{\mathrm{e}}$ & $0.00 \pm 0.00^{\mathrm{e}}$ & $0.00 \pm 0.00^{\mathrm{f}}$ & $0.00 \pm 0.00^{\mathrm{f}}$ & ND & ND \\
\hline 3 & $640 \pm 28.28^{\mathrm{f}}$ & $590 \pm 28.28^{\mathrm{h}}$ & $0.00 \pm 0.00^{\mathrm{e}}$ & $0.00 \pm 0.00^{\mathrm{e}}$ & $0.00 \pm 0.00^{\mathrm{f}}$ & $0.00 \pm 0.00^{\mathrm{f}}$ & ND & ND \\
\hline 4 & $2200 \pm 28.82^{\mathrm{e}}$ & $1830 \pm 28.82^{\mathrm{g}}$ & $0.00 \pm 0.00^{\mathrm{e}}$ & $0.00 \pm 0.00^{\mathrm{e}}$ & $0.00 \pm 0.00^{\mathrm{f}}$ & $0.00 \pm 0.00^{\mathrm{f}}$ & $\mathrm{ND}$ & ND \\
\hline 5 & $2330 \pm 28.82^{\mathrm{e}}$ & $1910 \pm 0.00^{\mathrm{f}}$ & $0.00 \pm 0.00^{\mathrm{e}}$ & $0.00 \pm 0.00^{\circ}$ & $10 \pm 0.00^{\mathrm{e}}$ & $10 \pm 0.00^{\circ}$ & ND & $\mathrm{ND}$ \\
\hline 6 & $2520 \pm 0.71^{\mathrm{e}}$ & $2420 \pm 28.82^{\mathrm{e}}$ & $20 \pm 7.07^{d}$ & $20 \pm 0.00^{\mathrm{d}}$ & $20 \pm 7.07^{\mathrm{d}}$ & $20 \pm 0.00^{\mathrm{d}}$ & $\mathrm{ND}$ & ND \\
\hline 7 & $6610 \pm 28.82^{\mathrm{d}}$ & $5770 \pm 28.82^{\mathrm{d}}$ & $20 \pm 7.07^{d}$ & $20 \pm 7.07^{\mathrm{d}}$ & $20 \pm 7.07^{\mathrm{d}}$ & $20 \pm 7.07^{\mathrm{d}}$ & $\mathrm{ND}$ & $\mathrm{ND}$ \\
\hline 8 & $8830 \pm 28.82^{\mathrm{c}}$ & $8020 \pm 0.00^{\mathrm{c}}$ & $25 \pm 0.00^{\mathrm{c}}$ & $25 \pm 0.00^{\mathrm{c}}$ & $25 \pm 7.07^{\circ}$ & $30 \pm 0.00^{\mathrm{c}}$ & $\mathrm{ND}$ & ND \\
\hline 9 & $90800 \pm 0.00^{\mathrm{b}}$ & $85700 \pm 0.00^{\mathrm{b}}$ & $30 \pm 7.07^{\mathrm{b}}$ & $30 \pm 0.00^{\mathrm{b}}$ & $40 \pm 0.00^{\mathrm{b}}$ & $40 \pm 0.00^{\mathrm{b}}$ & $\mathrm{ND}$ & $\mathrm{ND}$ \\
\hline 10 & $137000 \pm 0.00^{\mathrm{a}}$ & $122000 \pm 0.00^{\mathrm{a}}$ & $40 \pm 0.00^{\mathrm{a}}$ & $40 \pm 0.00^{\mathrm{a}}$ & $50 \pm 7.07^{\mathrm{a}}$ & $50 \pm 0.00^{\mathrm{a}}$ & $\mathrm{ND}$ & $\mathrm{ND}$ \\
\hline
\end{tabular}

Values are means \pm standard deviations of duplicate scores. Values followed by different superscript in column are significantly different $(\mathrm{p}<0.05)$. TVC Total Plate Count $(\mathrm{CFU} / \mathrm{g})$, MC Mould Count $(\mathrm{CFU} / \mathrm{g})$, YC Yeast Count (CFU/g), ND Not Detected.

Mold was absent in both samples during the first five weeks of storage. Mold growth was noticed at the sixth week of storage. Mold grew insignificantly ( $\mathrm{p}>0.05$ ) from $20 \mathrm{CFU} / \mathrm{g}$ to $25 \mathrm{CFU} / \mathrm{g}$ in both samples from the sixth week to the eighth week, however, grew significantly $(\mathrm{p}<0.05)$ from $30 \mathrm{CFU} / \mathrm{g}$ to $40 \mathrm{CFU} / \mathrm{g}$ for both samples from the ninth week to the tenth week of storage. The total bacteria count of the samples was low after the first 
day of storage and increased insignificantly $(p>0.05)$ but still below the recommended levels for human consumption $\left(10^{5} \mathrm{CFU} / \mathrm{g}\right)$ (Standards Organisation of Nigeria, 2009).At the end of the ninth week, there was a significant $(\mathrm{p}<0.05)$ multiplication of bacteria for the samples on storage.

Yeast was absent in both samples during the first four weeks of storage. Yeast growth was noticed at the fifth week of storage. Yeast grew significantly $(\mathrm{p}<0.05)$ from $10 \mathrm{CFU} / \mathrm{g}$ to $50 \mathrm{CFU} / \mathrm{g}$ for both samples from the fifth through to the tenth week of storage. Coliform was absent in the samples throughout the storage period. The absence of yeast and mold at the initial storage period and coliform throughout the storage period could be due to the effectiveness of pasteurization and packaging, low water activity and hygienic processing environment (Gould, 1983).

\subsection{Changes in Sensory Properties With Time}

The changes in the sensory properties of the samples are shown in Tables 3, 4, 5 and 6. It was observed that the freshly prepared samples (S1 and S2) were not significantly different ( $>0.05)$ in appearance, colour, taste and overall acceptability from the commercial sample.

Table 3. Weekly mean sensory scores for appearance

\begin{tabular}{llllllllll}
\hline Sample & Week 0 & Week 1 & Week 2 & Week 3 & Week 4 & Week 5 & Week 6 & Week 7 & Week 8 \\
\hline $\mathrm{S}_{1}$ & $7.2 \pm 0.79^{\mathrm{a}}$ & $7.2 \pm 0.79^{\mathrm{a}}$ & $7.3 \pm 0.67^{\mathrm{a}}$ & $7.2 \pm 0.79^{\mathrm{a}}$ & $7.2 \pm 0.79^{\mathrm{a}}$ & $7.1 \pm 0.74^{\mathrm{a}}$ & $7.3 \pm 0.67^{\mathrm{a}}$ & $7.4 \pm 0.52^{\mathrm{a}}$ & $8.1 \pm 0.57^{\mathrm{a}}$ \\
$\mathrm{S}_{2}$ & $7.4 \pm 0.52^{\mathrm{a}}$ & $7.3 \pm 0.67^{\mathrm{a}}$ & $7.2 \pm 0.79^{\mathrm{a}}$ & $7.3 \pm 0.82^{\mathrm{a}}$ & $7.3 \pm 0.67^{\mathrm{a}}$ & $7.2 \pm 0.79^{\mathrm{a}}$ & $7.3 \pm 0.67^{\mathrm{a}}$ & $7.3 \pm 0.48^{\mathrm{a}}$ & $8.2 \pm 0.63^{\mathrm{a}}$ \\
$\mathrm{S}_{3}$ & $7.2 \pm 0.79^{\mathrm{a}}$ & $7.2 \pm 0.79^{\mathrm{a}}$ & $6.8 \pm 0.63^{\mathrm{b}}$ & $6.6 \pm 0.70^{\mathrm{b}}$ & $5.8 \pm 0.79^{\mathrm{b}}$ & $5.2 \pm 0.42^{\mathrm{b}}$ & $4.8 \pm 0.79^{\mathrm{b}}$ & $3.8 \pm 0.79^{\mathrm{b}}$ & $3.7 \pm 1.05^{\mathrm{b}}$ \\
$\mathrm{S}_{4}$ & $7.4 \pm 0.52^{\mathrm{a}}$ & $7.1 \pm 0.74^{\mathrm{a}}$ & $6.9 \pm 0.74^{\mathrm{b}}$ & $6.8 \pm 0.63^{\mathrm{b}}$ & $6.0 \pm 0.67^{\mathrm{b}}$ & $5.2 \pm 0.63^{\mathrm{b}}$ & $4.9 \pm 0.74^{\mathrm{b}}$ & $4.2 \pm 0.63^{\mathrm{b}}$ & $2.0 \pm 0.81^{\mathrm{c}}$ \\
$\mathrm{S}_{5}$ & $7.4 \pm 0.52^{\mathrm{a}}$ & $7.1 \pm 0.74^{\mathrm{a}}$ & $7.2 \pm 0.79^{\mathrm{a}}$ & $7.2 \pm 0.79^{\mathrm{a}}$ & $7.1 \pm 0.74^{\mathrm{a}}$ & $7.1 \pm 0.74^{\mathrm{a}}$ & $7.2 \pm 0.63^{\mathrm{a}}$ & $7.3 \pm 0.67^{\mathrm{a}}$ & $8.0 \pm 0.67^{\mathrm{a}}$ \\
\hline
\end{tabular}

Values are means \pm standard deviations of 32 scores. Values followed by different superscript in column are significantly different $(\mathrm{p}<0.05)$. Key: $\mathrm{S}_{1}$ Fresh De Rica Puree, $\mathrm{S}_{2}$ Fresh Roma Puree, $\mathrm{S}_{3}$ Stored De Rica Puree, $\mathrm{S}_{4}$ Stored Roma Puree, $\mathrm{S}_{5}$ Commercial Sample.

Table 4. Weekly mean sensory scores for colour

\begin{tabular}{llllllllll}
\hline Sample & Week 0 & Week 1 & Week 2 & Week 3 & Week 4 & Week 5 & Week 6 & Week 7 & Week 8 \\
\hline $\mathrm{S}_{1}$ & $7.6 \pm 0.52 \mathrm{a}$ & $7.5 \pm 0.71 \mathrm{a}$ & $7.3 \pm 0.48^{\mathrm{a}}$ & $7.2 \pm 0.42^{\mathrm{a}}$ & $7.2 \pm 0.32^{\mathrm{a}}$ & $7.1 \pm 0.32^{\mathrm{a}}$ & $7.3 \pm 0.48^{\mathrm{a}}$ & $7.8 \pm 0.79^{\mathrm{a}}$ & $7.8 \pm 0.63^{\mathrm{a}}$ \\
$\mathrm{S}_{2}$ & $7.5 \pm 0.53 \mathrm{a}$ & $7.6 \pm 0.70 \mathrm{a}$ & $7.4 \pm 0.52^{\mathrm{a}}$ & $7.2 \pm 0.42^{\mathrm{a}}$ & $7.3 \pm 0.42^{\mathrm{a}}$ & $7.2 \pm 0.48^{\mathrm{a}}$ & $7.3 \pm 0.48^{\mathrm{a}}$ & $7.7 \pm 0.82^{\mathrm{a}}$ & $8.2 \pm 0.42^{\mathrm{a}}$ \\
$\mathrm{S}_{3}$ & $7.6 \pm 0.52 \mathrm{a}$ & $7.1 \pm 0.57 \mathrm{a}$ & $6.8 \pm 0.63^{\mathrm{b}}$ & $6.6 \pm 0.51^{\mathrm{b}}$ & $5.8 \pm 0.52^{\mathrm{b}}$ & $5.2 \pm 0.52^{\mathrm{b}}$ & $5.4 \pm 0.70^{\mathrm{b}}$ & $3.6 \pm 0.52^{\mathrm{b}}$ & $3.4 \pm 0.52^{\mathrm{b}}$ \\
$\mathrm{S}_{4}$ & $7.5 \pm 0.53 \mathrm{a}$ & $7.1 \pm 0.57 \mathrm{a}$ & $6.6 \pm 0.52^{\mathrm{b}}$ & $6.5 \pm 0.53^{\mathrm{b}}$ & $6.0 \pm 0.63^{\mathrm{b}}$ & $5.2 \pm 0.67^{\mathrm{b}}$ & $5.3 \pm 0.95^{\mathrm{b}}$ & $3.3 \pm 0.48^{\mathrm{b}}$ & $3.2 \pm 0.79^{\mathrm{b}}$ \\
$\mathrm{S}_{5}$ & $7.5 \pm 0.53 \mathrm{a}$ & $7.4 \pm 0.70 \mathrm{a}$ & $7.2 \pm 0.42^{\mathrm{a}}$ & $7.1 \pm 0.32^{\mathrm{a}}$ & $7.1 \pm 0.42^{\mathrm{a}}$ & $7.1 \pm 0.48^{\mathrm{a}}$ & $7.2 \pm 0.63^{\mathrm{a}}$ & $7.6 \pm 0.84^{\mathrm{a}}$ & $7.8 \pm 0.53^{\mathrm{a}}$ \\
\hline
\end{tabular}

Values are mean $\mathrm{s} \pm$ standard deviations of 32 scores. Values followed by different superscript in column are significantly different $(\mathrm{p}<0.05)$. Key: $\mathrm{S}_{1}$ Fresh De Rica Puree, $\mathrm{S}_{2}$ Fresh Roma Puree, $\mathrm{S}_{3}$ Stored De Rica Puree, $\mathrm{S}_{4}$ Stored Roma Puree, $\mathrm{S}_{5}$ Commercial Sample.

Table 5. Weekly mean sensory scores for taste

\begin{tabular}{llllllllll}
\hline Sample & week 0 & week1 & week2 & week3 & week4 & week5 & week6 & week7 & week8 \\
\hline $\mathrm{S}_{1}$ & $7.9 \pm 0.57^{\mathrm{a}}$ & $7.1 \pm 0.57^{\mathrm{a}}$ & $7.2 \pm 0.56^{\mathrm{a}}$ & $7.4 \pm 0.70^{\mathrm{a}}$ & $7.4 \pm 0.70^{\mathrm{a}}$ & $7.3 \pm 0.48^{\mathrm{a}}$ & $7.4 \pm 0.84^{\mathrm{a}}$ & $7.5 \pm 0.71^{\mathrm{a}}$ & $7.7 \pm 0.82^{\mathrm{a}}$ \\
$\mathrm{S}_{2}$ & $7.8 \pm 0.63^{\mathrm{a}}$ & $7.2 \pm 0.63^{\mathrm{a}}$ & $7.3 \pm 0.74^{\mathrm{a}}$ & $7.4 \pm 0.70^{\mathrm{a}}$ & $7.2 \pm 0.42^{\mathrm{a}}$ & $7.4 \pm 0.70^{\mathrm{a}}$ & $7.5 \pm 0.97^{\mathrm{a}}$ & $7.2 \pm 0.42^{\mathrm{a}}$ & $7.5 \pm 0.53^{\mathrm{a}}$ \\
$\mathrm{S}_{3}$ & $7.9 \pm 0.57^{\mathrm{a}}$ & $7.1 \pm 0.57^{\mathrm{a}}$ & $6.9 \pm 0.48^{\mathrm{b}}$ & $6.9 \pm 0.57^{\mathrm{b}}$ & $5.8 \pm 1.03^{\mathrm{b}}$ & $4.6 \pm 1.26^{\mathrm{b}}$ & $5.2 \pm 0.42^{\mathrm{b}}$ & $3.0 \pm 0.49^{\mathrm{b}}$ & $2.5 \pm 0.53^{\mathrm{b}}$ \\
$\mathrm{S}_{4}$ & $7.8 \pm 0.63^{\mathrm{a}}$ & $7.0 \pm 0.47^{\mathrm{a}}$ & $7.0 \pm 0.47^{\mathrm{b}}$ & $7.0 \pm 0.00^{\mathrm{b}}$ & $5.6 \pm 1.26^{\mathrm{b}}$ & $4.8 \pm 1.23^{\mathrm{b}}$ & $4.8 \pm 0.63^{\mathrm{b}}$ & $2.8 \pm 0.92^{\mathrm{b}}$ & $2.1 \pm 0.74^{\mathrm{b}}$ \\
$\mathrm{S}_{5}$ & $7.8 \pm 0.63^{\mathrm{a}}$ & $7.0 \pm 0.47^{\mathrm{a}}$ & $7.2 \pm 0.63^{\mathrm{a}}$ & $7.4 \pm 0.71^{\mathrm{a}}$ & $7.3 \pm 0.48^{\mathrm{a}}$ & $7.2 \pm 0.63^{\mathrm{a}}$ & $7.3 \pm 0.78^{\mathrm{a}}$ & $7.2 \pm 0.42^{\mathrm{a}}$ & $7.7 \pm 0.82^{\mathrm{a}}$ \\
\hline
\end{tabular}

Values are means \pm standard deviations of 32 scores. Values followed by different superscript in column are significantly different $(\mathrm{p}<0.05)$. Key: $\mathrm{S}_{1}$ Fresh De Rica Puree, $\mathrm{S}_{2}$ Fresh Roma Puree, $\mathrm{S}_{3}$ Stored De Rica Puree, $\mathrm{S}_{4}$ Stored Roma Puree, $\mathrm{S}_{5}$ Commercial Sample. 
Table 6. Weekly mean sensory scores for overall acceptability

\begin{tabular}{llllllllll}
\hline Sample & week 0 & week1 & week2 & week3 & week4 & week5 & week6 & week7 & week8 \\
\hline $\mathrm{S}_{1}$ & $7.6 \pm 0.70^{\mathrm{a}}$ & $7.7 \pm 0.82^{\mathrm{a}}$ & $7.4 \pm 0.52^{\mathrm{a}}$ & $7.4 \pm 0.52^{\mathrm{a}}$ & $7.3 \pm 0.48^{\mathrm{a}}$ & $7.2 \pm 0.63^{\mathrm{a}}$ & $7.4 \pm 0.52^{\mathrm{a}}$ & $7.7 \pm 0.67^{\mathrm{a}}$ & $8.0 \pm 0.94^{\mathrm{a}}$ \\
$\mathrm{S}_{2}$ & $7.9 \pm 0.57^{\mathrm{a}}$ & $7.5 \pm 0.53^{\mathrm{a}}$ & $7.4 \pm 0.42^{\mathrm{a}}$ & $7.3 \pm 0.48^{\mathrm{a}}$ & $7.4 \pm 0.52^{\mathrm{a}}$ & $7.4 \pm 0.52^{\mathrm{a}}$ & $7.5 \pm 0.53^{\mathrm{a}}$ & $7.9 \pm 0.74^{\mathrm{a}}$ & $8.1 \pm 0.88^{\mathrm{a}}$ \\
$\mathrm{S}_{3}$ & $7.6 \pm 0.70^{\mathrm{a}}$ & $7.4 \pm 0.52^{\mathrm{a}}$ & $6.8 \pm 0.63^{\mathrm{b}}$ & $6.8 \pm 0.42^{\mathrm{b}}$ & $6.1 \pm 0.74^{\mathrm{b}}$ & $6.1 \pm 0.74^{\mathrm{b}}$ & $5.9 \pm 0.74^{\mathrm{b}}$ & $3.4 \pm 0.84^{\mathrm{b}}$ & $2.3 \pm 0.48^{\mathrm{b}}$ \\
$\mathrm{S}_{4}$ & $7.9 \pm 0.57^{\mathrm{a}}$ & $7.4 \pm 0.52^{\mathrm{a}}$ & $6.6 \pm 0.53^{\mathrm{b}}$ & $6.6 \pm 0.52^{\mathrm{b}}$ & $6.3 \pm 0.48^{\mathrm{b}}$ & $5.9 \pm 0.74^{\mathrm{b}}$ & $5.8 \pm 0.79^{\mathrm{b}}$ & $3.2 \pm 0.79^{\mathrm{b}}$ & $2.0 \pm 0.47^{\mathrm{b}}$ \\
$\mathrm{S}_{5}$ & $7.7 \pm 0.48^{\mathrm{a}}$ & $7.7 \pm 0.82^{\mathrm{a}}$ & $7.5 \pm 0.53^{\mathrm{a}}$ & $7.5 \pm 0.53^{\mathrm{a}}$ & $7.3 \pm 0.48^{\mathrm{a}}$ & $7.3 \pm 0.48^{\mathrm{a}}$ & $7.3 \pm 0.48^{\mathrm{a}}$ & $7.7 \pm 0.67^{\mathrm{a}}$ & $7.9 \pm 0.86^{\mathrm{a}}$ \\
\hline
\end{tabular}

Values are means \pm standard deviations of 32 scores. Values followed by different superscript in column are significantly different $(\mathrm{p}<0.05)$. Key: $\mathrm{S}_{1}$ Fresh De Rica Puree, $\mathrm{S}_{2}$ Fresh Roma Puree, $\mathrm{S}_{3}$ Stored De Rica Puree, $\mathrm{S}_{4}$ Stored Roma Puree, $\mathrm{S}_{5}$ Commercial Sample.

Table 3 shows that there was no significant difference $(\mathrm{p}>0.05)$ in term of appearance between the stored (S3 and $\mathrm{S} 4)$, fresh (S1 and S2) and the commercial (S5) samples during the first three weeks of storage. The stored samples however, showed a significant difference $(\mathrm{p}<0.05)$ from the fresh and market samples from the fourth week of storage and beyond.

Tables 4, 5 and 6 showed that there was no significant difference $(p>0.05)$ in terms of colour, taste and overall acceptability respectively between the stored, fresh and commercial samples within first week of storage. The stored samples showed a significant difference $(\mathrm{p} \leq 0.05)$ from fresh and commercial samples at the second week of storage onward.There was no significant $(\mathrm{p}>0.05)$ difference between the freshly produced De Rica puree, Roma puree and the commercial sample in appearance, colour, taste and overall acceptability before and during storage. The level of acceptance for both purees in appearance, colour, taste and overall acceptability decreased with time. Marked rejection of the purees was observed at the eight week of storage probably due to the offensive odour that became perceptible. Changes in colour during storage could probably be due to the formation of heterocyclic compounds and streicker aldehydes having a low sensory threshold (Adedeji et al., 2012). The characteristic sweet taste of tomato puree depends on the interaction between total sugar and titratable acidity (Malindo et al., 1995) therefore; changes in taste observed during storage could probably have been due to reduction in total sugar and titratable acidity.

\section{Conclusion}

This study showed that physicochemical, microbial and sensory properties of tomato purees are affected by the type of cultivar used. Roma puree had higher total solid, total soluble solids, chloride and sucrose while De Rica puree had higher titratable acidity and total insoluble solid throughout the storage period. The level of acceptance of both purees in appearance, colour, taste and overall acceptability decreased with time. Marked rejection of the purees was observed after the eight week of storage.

\section{References}

Adedeji, O. E., Anuonye, J. C., \& Karim, O. R. (2012). Effects of Storage Time on the Stability of Tomato Puree Produced using Hot-Break Method. Journal of Agricultural Research and Development, 11(1), 85-94.

A.O.A.C. (2000). Official methods of Analysis of the Association of official Analytical Chemists. (17th Edition) (pp. 12-20), Horowitz, Maryland.

Francisco, J., Sergio, B., Javier, C., Dar, P., Karin, J., \& Mar, P. (2009). Changes in Antioxidant Compounds during the Shelf Life of Commercial Tomato Juices in Different Packaging Materials. Journal of Agriulture and Food Chemistry, 57(15), 6815-6822. http://dx.doi.org/10.1021/jf900877c

Gould, N. A. (1983). Tomato Production, Processing and Technology. CTI Publishing, Baltimore.

Idowu, I. S. (2001). Processing and Preservation of Specific Food Commodity (1st Edition). Offa: Golden Publisher.

Ihekoronye, A. I., \& Ngoddy, P. O. (1985). Integrated Food Science For The Tropics (2nd Edition). London: Macmillian Publisher.

Kirk, R., \& Sawyer, R. (1991). Pearson's Composition and Analysis of Food (9th Edition), (pp. 253-256).

Levy, R. (2009). Vegetables That Contain Natural Toxins. California Master Gardener Handbook (pp. 643-644). ANR Publications. 
Malcolm, J. L. (1997). Nutrient Effects On Tomatoes, Effect of Nitrogen, Phosphorus, And Potassium Fertilizer On Fruit Yield And Composition Of Tomato Leaves. Journal of Agricultural and Food Chemistry, 7, 415. http://dx.doi.org/10.1021/jf60100a004

Malindo, T. M., Shewfelt, R. L., \& Scott, J. W. (1995). Flavor Quality of Fresh Tomatoes as affected by Sugar and Acid Levels. Post Harvest Biotechnology, 6, 103-110. http://dx.doi.org/10.1016/0925-5214(94)00052-T

Moyer, J. C. (2000). Relationship between Pyrilidone carboxylic acid off flavours in beet Puree. Journal of Agriculture and Food Chemistry, 6, 604-606.

Nielsen, S. S. (1998). Introduction to Food Analysis (pp. 60-61) Missouri: Aspen Publisher.

Omole, J. O. (2002). Food Biochemistry; Emphasis on Fruits and Vegetables (5th Edition) (pp. 14-21). David Business Systems, Lagos.

Opara, U. L., Al-Ani, M. R., \& Al-Rhahbi, N. M. (2012). Effect of fruit ripening stage on the physicochemical properties, nutritional composition and antioxidant components of tomato. Food and Bioprocess Technology, 5(8), 3236-3243. http://dx.doi.org/10.1007/s11947-011-0693-5

Peet, M. (2008). Crop Profiles - Tomato. International Journal of Food Science and Nutrition, 27, 145-152.

Roberts, D., \& Greenwood, M. (2003). Practical Food Microbiology, Massachusetts 02148-5018, USA, Blackwell Publishing.

S.O.N. (2009). Standards Organisation of Nigeria Manuals.

Standard Methods Committee of the American Society for Testing Materials. (2007). A.S.T.M. Philladelphia, 18, 24-26.

Temesgen, M., Workneh, T. S., \& Bultossa, G. (2011). Effect of tomato cultivars, honey finisher and processing methods on quality of tomato ketchup. African Journal of Biotechnology, 10(80), 18516-185. http://dx.doi.org/10.5897/AJB11.532

\section{Copyrights}

Copyright for this article is retained by the author(s), with first publication rights granted to the journal.

This is an open-access article distributed under the terms and conditions of the Creative Commons Attribution license (http://creativecommons.org/licenses/by/3.0/). 